\title{
Serological response of patients infected with Salmonella typhi
}

\author{
H Chart, B Rowe, J S Cheesbrough
}

\begin{abstract}
Aims-To evaluate a rapid immunoblotting procedure for providing evidence of infection with Salmonella typhi using 73 sera from patients infected with $S$ typhi. Methods-A sodium dodecyl sulphatepolyacrylamide gel electrophoresis (SDSPAGE)/immunoblotting procedure using lipopolysaccharide (LPS, $O=9,12)$ and flagellar $(\mathrm{H}=\mathrm{d})$ antigens was used.

Results-Seventy two of 73 sera contained antibodies to LPS, 40 sera also contained antibodies to $\mathrm{H}=\mathbf{d}$ flagellar antigens. Analysis of acute and convalescent sera showed that only $62 \%$ of patients produced antibodies to flagellar antigens.

Conclusions-The SDS-PAGE/immunoblotting procedure provided a rapid method for providing serological evidence of infection with $S$ typhi.

( Clin Pathol 1997;50:944-946)
\end{abstract}

Keywords: Salmonella typhi; typhoid; serodiagnosis

Typhoid fever continues to be a major public health problem in developing countries, and although its incidence is lower in northern Europe and North America, cases of typhoid are found frequently as a result of travellers returning from endemic areas. The diagnosis can be confirmed by blood culture in the majority of patients who have not received the appropriate antibiotics. Although cultures of stool, urine, and bone marrow yield some additional isolates, in a small proportion of cases all cultures may be negative for Salmonella typhi and the diagnosis then rests on a combination of clinical and epidemiological features. In such cases, serological methods offer an alternative approach and, therefore, retain an important place in the diagnosis of typhoid.

The antigenic structure of $S$ typhi is (Vi) 9, $12: \mathrm{d}^{1}$; and infection with $S$ typhi may result in the production of serum antibodies to the $\mathrm{O}=9,12$ somatic, the $\mathrm{H}=\mathrm{d}$ flagellar, and the "Vi" capsular antigens. For many years the Widal agglutination test has been used to detect antibodies to these antigens ${ }^{2}$; however, more modern immunoassays have been considered as a replacement.

In a previous study, the techniques of sodium dodecyl sulphate-polyacrylamide gel electrophoresis (SDS-PAGE) and immunoblotting were used as a comparison with the established Widal technique for the examination of sera for antibodies to the lipopolysaccharide (LPS) and flagellar antigens of $S$ typhi. ${ }^{3}$
In the present study, sera from patients who were all culture positive for $S$ typh $i$ were used to evaluate this rapid form of serodiagnosis more fully.

\section{Methods}

BACTERIA

Salmonella enteritidis strain P132344 $(\mathrm{O}=1,9,12 ; \mathrm{H}=\mathrm{g}, \mathrm{m})$ was used for the preparation of LPS and $S$ meunchen strain JT54 $(\mathrm{O}=6,8 ; \mathrm{H}=\mathrm{d})$ was used to prepare flagella. ${ }^{3}$ Bacteria were grown on nutrient agar $\left(37^{\circ} \mathrm{C}\right.$ for 16 hours) from Dorset's egg agar slopes stored in the Laboratory of Enteric Pathogens, London.

\section{PATIENTS}

The 47 patients ( 33 male, 14 female) involved in the study had typhoid fever and were aged between 18 and 50 years. All were hospitalised in the Infectious Disease Hospital, Kuwait. They were expatriate workers from Kuwait (3), Jordan (3), Syria (2), Iraq (1), India (11), Bangladesh (6), Pakistan (13), Sri Lanka (2), unknown (6). Patients were all culture positive for either blood or faecal $S$ typhi.

SERA

Seventy three serum samples were obtained from the 47 patients. Both acute and convalescent sera were obtained from 26 patients, and either an acute or a convalescent serum was obtained for 21 patients. Twelve sera were from healthy controls from the United Kingdom, their vaccination details were not known. All sera were stored at $-30^{\circ} \mathrm{C}$ until used.

\section{LIPOPOLYSACCHARIDE}

Lipopolysaccharide was prepared from $S$ enteritidis strain P132344, using proteinase $\mathrm{K}$ (Sigma, Poole, Dorset, UK) and hot phenol extraction as described previously. ${ }^{3}$ Outer membranes prepared from $S$ enteritidis formed the basis for hot phenol extraction using the method of Westphal and Jann. ${ }^{4}$

\section{FLAGELLA}

Flagella were extracted from $S$ meunchen strain JT54. ${ }^{2}$ Bacteria harvested from $6 \times 15 \mathrm{~cm}$ nutrient agar plates were suspended in saline and the preparation was incubated at $60^{\circ} \mathrm{C}$ for 30 minutes. Bacteria were sedimented by centrifugation (12 $500 \times g$ for 10 minutes) and the supernatant containing extracted flagella was removed and stored at $-30^{\circ} \mathrm{C}$. The protein concentration of flagellar preparations was determined using the method of Lowry et $a l^{5}{ }^{5}$. and the $S$ meunchen flagellar subunit size was 


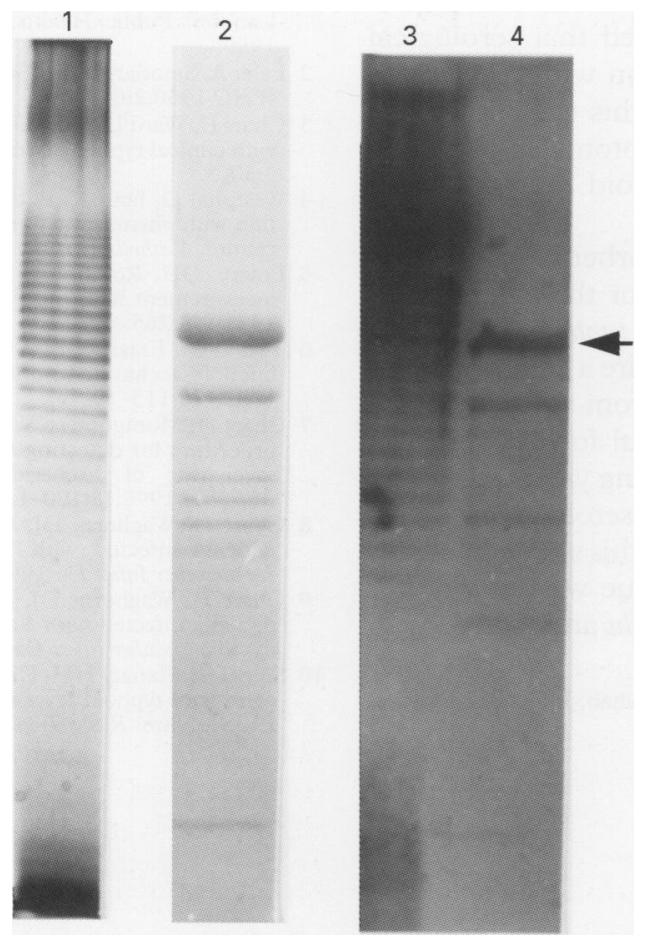

Figure 1 Seventy two sera contained antibodies to the lipopolysaccharide (LPS) of S enteritidis (lane 1), giving a strong reaction by immunoblot (lane 2). Forty sera also contained antibodies to the $65 \mathrm{kDa}$ flagellar subunits of $S$ meunchen (lane 3), as shown by the immunoblot arrowed in lane 4.

Table 1 Analysis of 73 serum samples from 47 patients culture-positive for antibodies to antigens $O=9,12$ and $H=d$

\begin{tabular}{lll}
\hline & \multicolumn{3}{l}{ Antibodies to } \\
\cline { 2 - 3 } Sera & $O=9,12$ & $H=d$ \\
\hline Acute sera $(\mathrm{n}=26)^{\star}$ & 25 & 16 \\
Convalescent sera $(\mathrm{n}=26)$ & 26 & 18 \\
Acute only $(\mathrm{n}=16)$ & 16 & 11 \\
Convalescent only $(\mathrm{n}=5)$ & 5 & 3 \\
\hline$\star$ Number of patients. & &
\end{tabular}

determined by performing SDS-PAGE alongside a commercial preparation of protein molecular weight standards (Bio-Rad, Hemel Hempstead, UK).

\section{SDS-PAGE/IMMUNOBLOTTING}

SDS-PAGE and immunoblotting were performed $^{2}$ using an Atto mini gel system (Genetic Research Instruments, Dunmow, Essex, UK). For SDS-PAGE, $1 \mu \mathrm{g}$ of LPS or $10 \mu \mathrm{g}$ flagellar protein was loaded per lane on to a gel comprising a $4.5 \%$ stacking gel and a $12.5 \%$ separation gel. Following electrophoresis (50 mAmps for 30 minutes), resultant profiles were either stained for LPS using a silver stain for carbohydrate ${ }^{6}$ or used for immunoblotting and reaction with patients' antibodies. For immunoblotting, profiles were transferred on to nitrocellulose membranes (0.5 Amps for 1.5 hours), blocked with skimmed milk ( $3 \%$ dried milk powder in phosphate buffered saline (PBS)), and reacted with sera (30 $\mu$ l per lane). Immunoblots were then washed (three times) with PBS containing $0.05 \%$ Tween 20 , and bound antibodies detected with a goat antihuman polyvalent antibody conjugated with alkaline phosphatase
(Sigma). ${ }^{2}$ Antibody-antibody conjugate complexes were detected with an enzyme substrate comprising $20 \mathrm{ml}$ of $0.1 \mathrm{M}$ Tris, $0.09 \mathrm{M} \mathrm{NaCl}$, and $0.15 \mathrm{M} \mathrm{Mg} 2 \mathrm{Cl}_{2} 6 \mathrm{H}_{2} \mathrm{O}$ containing $90 \mu \mathrm{l}$ nitroblue tetrazolium (Sigma; $75 \mathrm{mg} / \mathrm{ml}$ in $70 \%$ aqueous dimethyl formamide) and $70 \mu \mathrm{l}$ of aqueous 5-bromo-4-chloro-3indolylphosphate (Sigma; $50 \mathrm{mg} / \mathrm{ml}) .^{7-9}$

\section{Results}

CONTROL SERA

The 12 control sera did not contain antibodies to the $\mathrm{O}=9,12 \mathrm{LPS}$, or $\mathrm{H}=\mathrm{d}$ flagellar antigens.

PATIENTS' SERA

Seventy two of 73 patients' sera contained antibodies binding to SDS-PAGE profiles of $\mathrm{O}=1,9,12$ LPS (fig 1, lane 1); fig 1 (lane 3) gives an example of a typical LPS immunoblot result. Forty sera also contained antibodies to the $\mathrm{H}=\mathrm{d}$ flagellar antigen, migrating as a band of $65 \mathrm{kDa}$ (fig 1, lane 2); fig 1 (lane 4) gives an example of a typical flagellar immunoblot result. The serum without antibodies to LPS contained antibodies to $\mathrm{H}=\mathrm{d}$ flagellar antigens.

The panel included acute and convalescent sera from 26 patients (table 1), 25 of the 26 acute sera contained antibodies to the $\mathrm{O}=9,12$ antigens while all of the 26 convalescent sera contained antibodies to these antigens (table 1). Sixteen of the 26 acute sera and 18 of the 26 convalescent sera contained antibodies to the $\mathrm{H}=\mathrm{d}$ antigen (table 1). Eight patients did not have antiflagellar antibodies in either acute or convalescent sera and two patients had antiflagellar antibodies in convalescent sera only (table 2).

\section{Discussion}

In the present study we used 73 sera from culture positive patients with typhoid to evaluate an immunoblotting procedure based on the $\mathrm{O}=9,12$ LPS antigens and $\mathrm{H}=\mathrm{d}$ flagellar antigens. Because $S$ enteritidis and $S$ typhi express the same $\mathrm{O}=9,12$ antigens, $S$ enteritidis was used to prepare LPS as a safety precaution. On its own, the presence of serum antibodies to the $\mathrm{O}=9,12$ LPS antigens is not a reliable indicator of infection with $S$ typhi, because patients infected with $S$ enteritidis have also been shown to produce antibodies to the $\mathrm{O}=9,12$ antigen. ${ }^{8}{ }^{9}$ However, the detection of serum antibodies to flagellar antigen $\mathrm{H}=\mathrm{d}$, reinforces the diagnosis. Although other serotypes of salmonella possess the $\mathrm{O}=9,12$ and $\mathrm{H}=\mathrm{d}$ antigens, these bacteria are isolated only very rarely ${ }^{9}$ and antibodies to the $\mathrm{O}=9,12$ and $\mathrm{H}=\mathrm{d}$ antigens would be highly indicative of infection with $S$ typhi in the UK.

Acute and convalescent sera were obtained from 26 patients. Of these, antibodies to the $\mathrm{H}=\mathrm{d}$ antigen could not be detected in either acute or convalescent sera from eight of these patients. Whether this was due to the lack of flagellar antigen expression during infection, or the inability of patients to produce antibodies to flagellar antigens, was unknown. However, this result showed that approximately one third of patients did not produce antibodies to these flagellar antigens, and that the inability to detect patients' antibodies to $\mathrm{H}=\mathrm{d}$ flagellar, 
should not rule out a possible infection with $S$ typhi. It should be recognised that serological tests for evidence of infection with $S$ typhi are not as reliable as culturing this organism from a patient, and patients' symptoms and any history of vaccination for typhoid must be taken into consideration.

Enzyme linked immunosorbent assays (ELISAs) have been described for the detection of antibodies to the LPS of $S$ typhi. ${ }^{310}$ Although such quantitative assays require a cut off value to delineate antibody positive from antibody negative sera, they are very useful for obtaining an antibody titre. Immunoblotting yields an easy to read qualitative result for the serology of patients with suspected typhoid, and this study illustrates the potential of the technique we describe for detecting antibodies to $S$ typh $i$ antigens.

We acknowledge the help of Dr J Shihab, Infectious Diseases Hospital, Kuwait.
1 Rowe B, Hall MLM. Kaufmann-White Scheme 1989. London: Public Health Laboratory Service Publication, 1989

2 Felix A. Standardizing of diagnostic agglutination tests. Bull WHO 1950;2:643-9.

3 Chart H, Ward LR, Rowe B. Serological response of patients with clinical typhoid. Serodiagn Immunother Infect Dis 1995; w:30-3.

4 Westphal O, Jann K. Bacterial lipopolysaccharides: extraction with phenol-water and further applications of the procedure. Methods Carbohydr Chem 1965;5:83-91.

5 Lowry, OH, Rosebrough N, Farr A, Randall, R. Protein measurement with the Folin phenol reagent. F Biol Chem 1951;193:265-8.

6 Tsai C-M, Frasch CE. A sensitive silver stain for detecting lipopolysaccharide in polyacrylamide gels. Analyt Biochem 1982;119:115-19.

7 Chart H, Montgomery S, Rowe B. A rapid immunoblotting procedure for detecting serum antibodies to the lipopolyprocedure for detecting serum antibodies to the lipopoly-
saccharide of Escherichia coli O157:H7. Letts Appl Microbiol 1994;18:100-1.

8 Chart H, Waghorn, DJ, Rowe B. Serological detection of patients infected with Salmonella enteritidis. Serodiagn Immunother Infect Dis 1994;6:79-81

9 Chart H, Waghorn, DJ, Rowe B. Serological response of patients infected with Salmonella enteritidis PT4. Serodiagn Immunother Infect Dis 1994;6:21-4.

10 Sippel JE, Hanafy HM, Diab AS, Prato C, Arroyo R. Serodiagnosis of typhoid fever in paediatric patients by anti-LPS ELISA. Trans R Soc Trop Med Hyg 1987;81:1022-6. 